UDC $331.1 ; 331.53$

\title{
WORLD MANAGEMENT
}

\author{
N O R B E R T T H O M, \\ Prof. em. Dr., \\ Prof. h. c. Dr. h. c. mult, \\ Ph.D., Professor, \\ Senior Fellow, Center of Competence for Public Management, \\ Senior Fellow, Center for Health Care Law and Management \\ Institute for Organization \\ and Human Resource Management \\ University of Bern, \\ Hochschulstrasse, 6, Bern, 3012, Switzerland
}

\section{TALENT MANAGEMENT BY MEANS OF “TRAINEE PROGRAMMES" *}

Talent management is one of the most important Human Resources Management tools worldwide; however, according to the assessment of thousands of HR managers, this is still far from perfect. The author presents the results of many empirical studies in Germanspeaking countries, focusing on the so-called "Trainee Programs" or "Programs for graduates". 130 trainee programs are systematically analyzed and conclusions and recommendations are provided.

Keywords: talent management; human resources management; trainee programmes.

References 4; Figure 1.

The importance of talent management, although highly valued, has significant gaps in its practical implementation. The opportunities to eliminate this drawback are "trainee programmes" ( $\mathrm{TrPr})$. They have a variety of goals, for example, the creation of a pool of highly skilled professionals for employers. However, even in the German-speaking space, which plays a leading role in the field of "trainee programs", there remains significant potential for further improvement.

Few issues in HR management have seen such growth in significance in recent times as has talent management. In 2010, Boston Consulting Group, in collaboration with the World Federation of Personnel Management Associations WFPMA, conducted a survey among $5561 \mathrm{HR}$ specialists around the globe, asking which fields of activity they expected to grow in importance in the future ("future importance") and how well they thought they were currently handled ("current capability") **. Regarding future importance, talent management was rated exceedingly high in the survey. At the same time, current capability in this area was assessed as particularly low. Considering this striking imbalance (fig.), the authors of the study concluded that there was a "strong need to act".

(C) Norbert Thom, 2019; e-mail: norbert.thom@bluewin.ch.

* More thoroughly this problem was considered by the author in [1].

** The Boston Consulting Group / World Federation of Personnel Management Associations (BCG/WFPMA). Creating People Advantage 2010: How companies can adapt their HR practices for volatile times, 2010, available at : https://www.bcgperspectives.com/content/articles/organization transformation_creating_people_advantage_2010/. 


\title{
СВІТОВИЙ МЕНЕДЖМЕНТ
}

\author{
H. T O M, \\ професор, доктор наук, старший науковий співробітник \\ Центру компетенції з державного управління, \\ стариий науковий співробітник \\ Центру права та управління охороною здоров'я \\ Інститут організацї та управління людськими ресурсами \\ Бернського університету, \\ Хохшульштрасе, 6, Берн, 3012, Швейцарія
}

\section{УПРАВЛІННЯ ТАЛАНОВИТОЮ МОЛОДДЮ ЧЕРЕЗ “ПРАКТИКАНТСЬКІ ПРОГРАМИ" *}

Управління талановитою молоддю $є$ одним з найважливіших інструментів управління персоналом у світі, проте, на думку великої кількості менеджерів з персоналу, воно все ще $\epsilon$ далеким від досконалості. Автор подає результати багатьох емпіричних досліджень у німецькомовних країнах, приділяючи особливу увагу так званим “програмам для стажистів" або “програмам для випускників". Систематично проаналізовано 130 програм стажувань, дано висновки та рекомендації.

Ключові слова: управління талановитою молоддю; управління людськими ресурсами; практикантські програми.

Бібл. 4; рис. 1.

Значення управління талановитими людьми (талантами), хоча й оцінюється високо, але в його практичній реалізації $€$ істотні прогалини. Можливістю для усунення цього недоліку є “практикантські програми” (далі - ПрП). Вони мають на меті різноманітні цілі, наприклад, створення для роботодавців пулу висококваліфікованих фахівців. Проте і в німецькомовному просторі, який відіграє провідну роль у сфері “практикантських програм”, залишається значний потенціал для подальшого покращення.

Останнім часом у сфері менеджменту персоналу такого ж великого значення, як управління талановитою молоддю, набули лише декілька тем. У 2010 р. консалтингова компанія "Бостонська Консалтингова Група" (далі - БКГ) (The Boston Consulting Group - BCG) спільно із Світовою федерацією асоціацій менеджменту персоналу (далі - СФАМП) (World Federation of Personel Management Associations WFPMA) опитали по всьому світу 5561 фахівця у галузі менеджменту персоналу стосовно тих майбутніх сфер діяльності, які набуватимуть дедалі більшого значення, а також наскільки добре, на їхню думку, вони сьогодні справляються з ними (поточні здібності) **. У цьому опитуванні надано високу оцінку "Управлінню талантами" (Managing talent) відносно їх майбутньої ролі. При цьому сучасне опанування даного напряму визнано занадто низьким. 3 приводу наявності очевидного контрасту (рис.) автори дослідження ініціюють нагальну необхідність змін.

(C) Норберт Том (Norbert Thom), 2019; e-mail: norbert.thom@bluewin.ch.

* Грунтовніше ця проблема розглядалась автором у [1].

** The Boston Consulting Group / World Federation of Personel Management Associations (BCG/WFPMA). Creating People Advantage 2010: How companies can adapt their HR practices for volatile times, 2010 [Електронний ресурс]. - Режим доступу : https://www.bcgperspectives.com/ content/articles/organization_transformation_creating_people_advantage_2010/. 


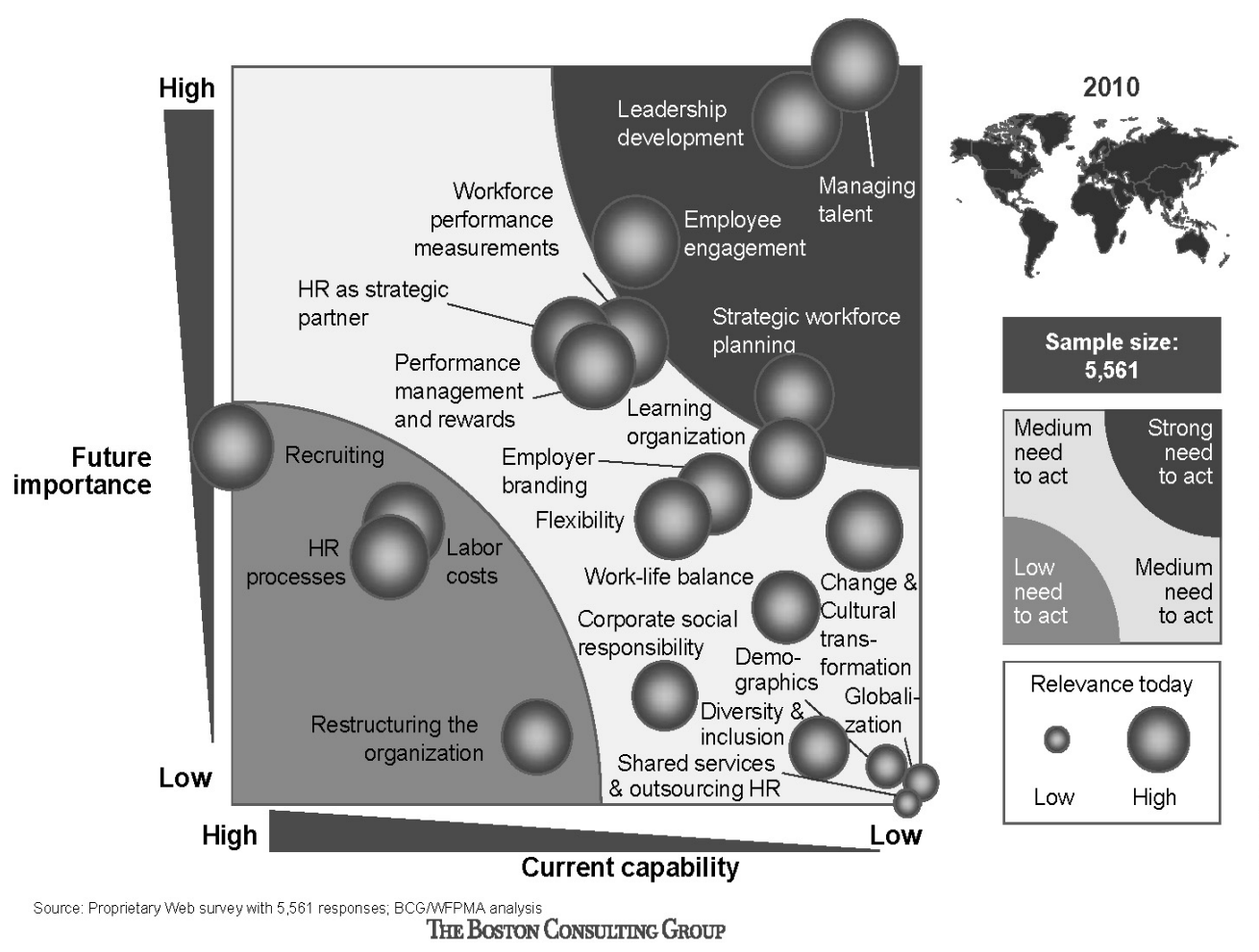

a) Talent, leadership development, engagement and workforce planning are the most critical HR topics 2010

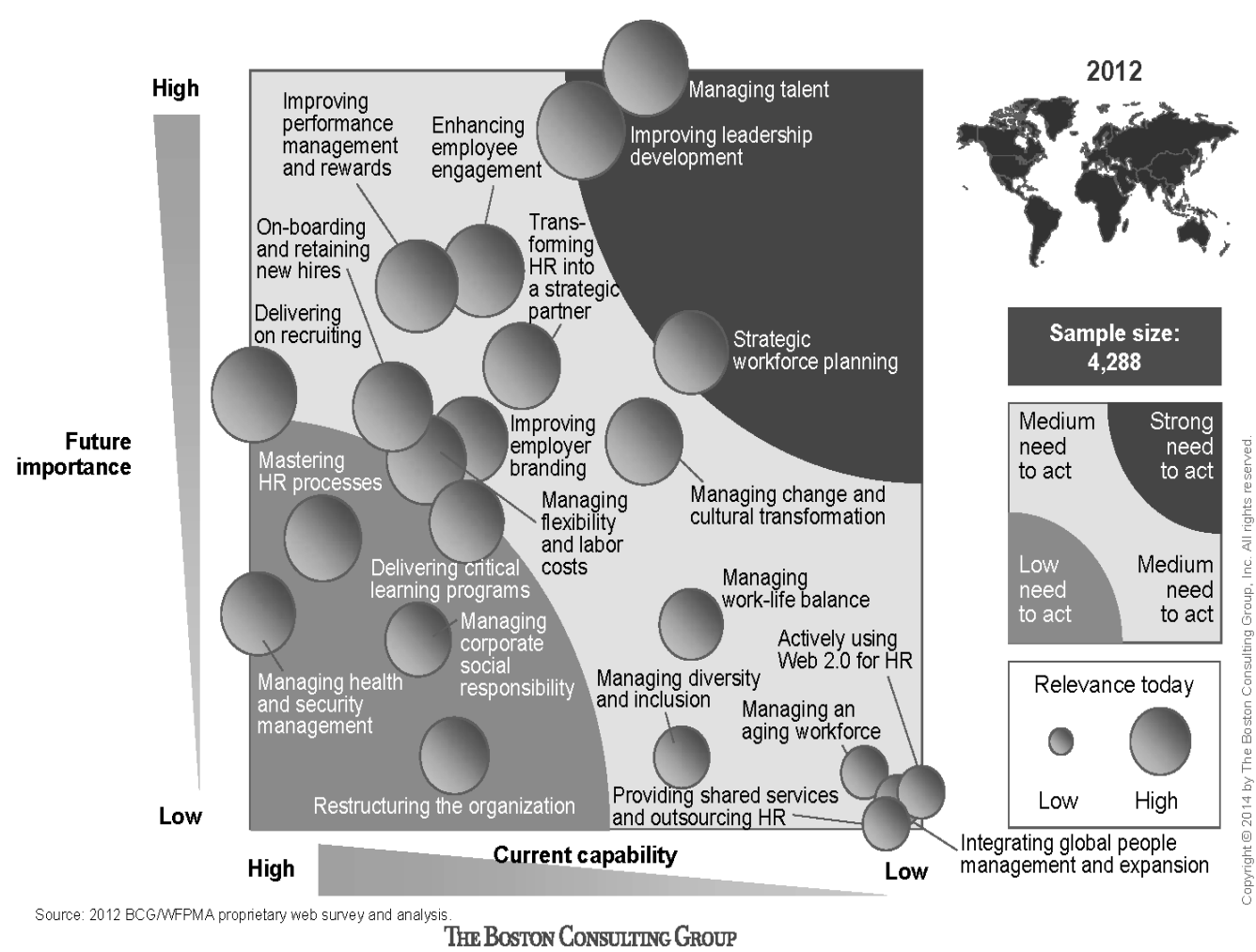

b) In 2012, most critical topics are managing talent, improving leadership development, and strategic workforce planning 
Toм H., c. $42-57$

Future importance: high, low

Leadership development

Workforce performance measurements

Managing talent

HR as strategic partner

Strategic workforce planning

Performance management and rewards

Learning organization

Recruiting

Employer branding

Flexibility

HR processes

Labor costs

Work-life balance

Corporate social responsibility

Change \& Cultural transformation

Demographics

Restructuring the organization

Diversity \& inclusion

Globalization

Shared services \& outsourcing HR

Current capability

Sample size: 5,561

Medium need to act

Strong need to act

Low need to act

Relevance today: low, high

a) Талант, розвиток лідерства, залученість і планування робочої сили - найважливіші теми у HR 2010

Важливість у майбутньому: висока, низька

Розвиток лідерських якостей

Показники ефективності трудових ресурсів

Залучення співробітників

Управління талантами

HR як стратегічний партнер

Стратегічне кадрове планування

Управління ефективністю і винагороди

Освітня організація

Рекрутинг

Брендинг роботодавця

Гнучкість

Кадрові процеси

Витрати на оплату праці

Баланс між роботою та особистим життям

Корпоративна соціальна відповідальність

Зміна і культурна трансформація

Демографія

Реструктуризація організації

Різноманітність і включення

Глобалізація

Спільні послуги та аутсорсинг HR

Поточні можливості

Розмір вибірки: 5561

Середня потреба діяти

Сильна потреба діяти

Низька потреба діяти

Актуальність сьогодні: низька, висока
Employee engagement

Future importance: high, low

Improving performance management and rewards

Enhancing employee engagement

Managing talent

Improving leadership development

On-boarding and retaining new hires

Transforming HR into a strategic partner

Delivering on recruiting

Strategic workforce planning

Mastering HR processes

Improving employer branding

Managing flexibility and labor costs

Managing change \& cultural transformation

Delivering critical learning programs

Managing work-life balance

Managing health and security management

Managing corporate social responsibility

Managing diversity \& inclusion

Actively using Web 2.0 for HR

Managing an aging workforce

Restructuring the organization

Providing shared services \& outsourcing HR

Integrating global people management and

expansion

Current capability: high, low

Sample size: 4,288

Medium need to act

Strong need to act

Low need to act

Relevance today: low, high
Важливість у майбутньому: висока, низька

Поліпшення управління продуктивністю і винагородами

Підвищення залученості співробітників

Управління талантами

Поліпшення розвитку лідерських якостей

Прийом на роботу та утримання нових співробітників

Перетворення HR на стратегічного партнера

Доставка на рекрутинг

Стратегічне кадрове планування

Освоєння HR процесів

Поліпшення брендинга роботодавця

Управління гнучкістю і трудозатратами

Управління змінами і культурною трансформацією

Поставка критичних навчальних програм

Управління балансом між роботою та особистим життям

Управління здоров'ям і безпекою

Управління корпоративною соціальною відповідальністю

Управління різноманітністю і включенням

Активне використання Web 2.0 для HR

Управління робочою силою, яка старіє

Реструктуризація організації

Інтерація та розширення глобального менедменту

Поточні можливості

Розмір вибірки: 4288

Середня потреба діяти

Сильна потреба діяти

Низька потреба діяти

Актуальність сьогодні: низька, висока
Надання загальних послуг та аутсорсинг HR

б) Управління талантами, поліпшення розвитку лідерства

і стратегічне кадрове планування - найважливіші теми HR у 2012 p. 


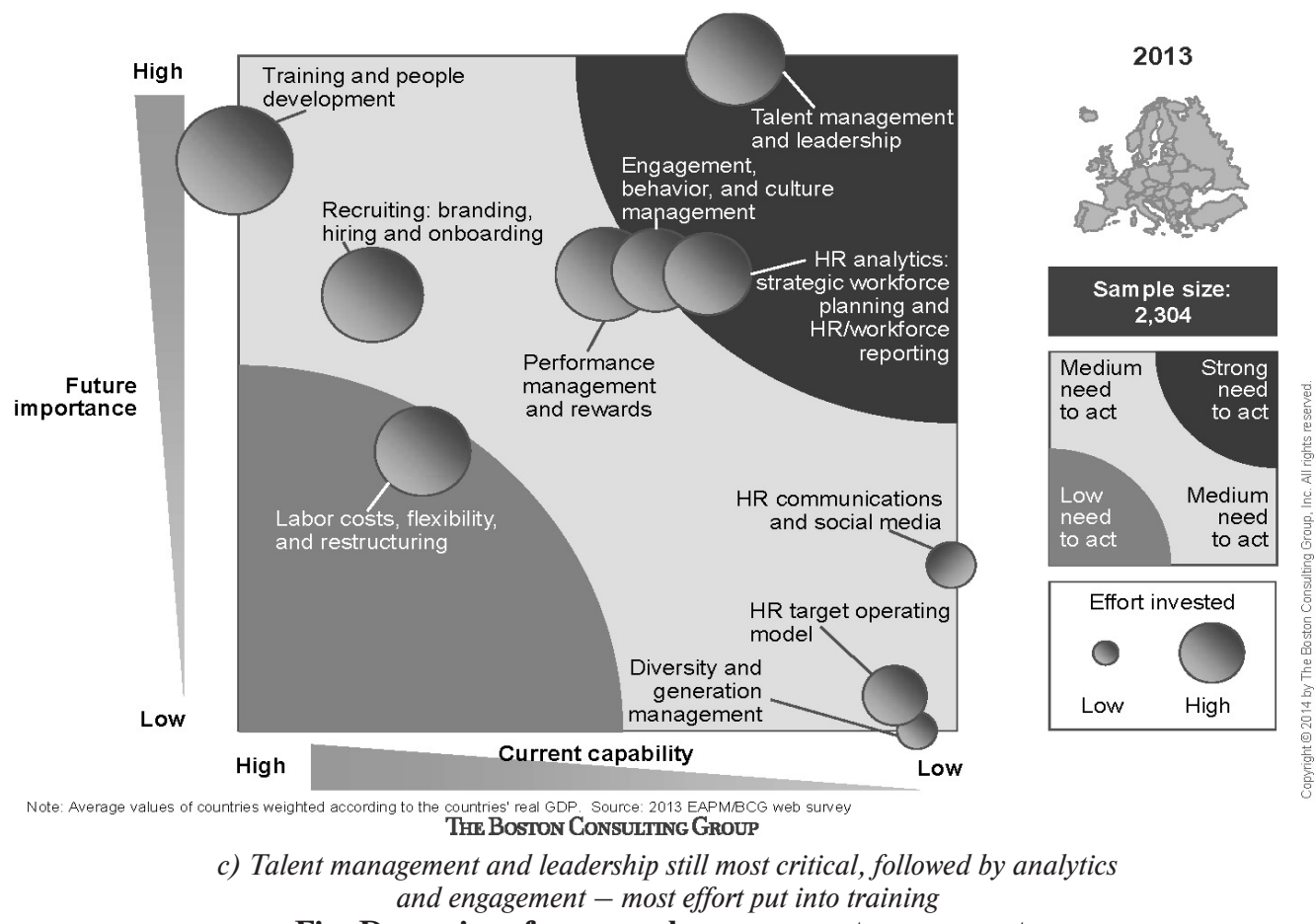

Fig. Dynamics of personnel management components

A follow-up study of 2011, covering 2039 HR managers in 35 European countries, came to a similar conclusion * [2]. In German-speaking Europe, vast amounts of knowledge and experience have been gathered over the past decades in the more specific area of fostering talented university graduates by means of so-called "trainee" or "graduate programmes". The present article gives an overview of this valuable body of know-how. It is intended to stimulate action among HR specialists around the globe, and to provide them with ideas. For this purpose, a number of preliminary remarks on the concepts of talent and talent management are in order.

In its most common use, the term talent refers to a special aptitude or giftedness in a certain field of human activity, or to a person who has such an aptitude. In the narrower sense the term assumes in the context of HR management, one feature of talented employees is that they tend to have gone through higher education. This, however, need not always be of an academic nature - just think of celebrity chefs or particularly gifted craftspeople. Furthermore, talented workers are highly motivated and love challenging tasks. They have an endless craving for continued professional training, and they satisfy this need whenever they can. Where these kinds of assets are crowned with highly developed social skills (e.g. with regard to communication and cooperation), such people are viewed as particularly talented. A talented person thus possesses key skills that are particularly useful and important for their employer's continued favorable development and overall success.

Talent management is defined by the authors of the mentioned BCG/WFPMA study as concerned with "attracting, developing and retaining all individuals with high potential - regardless of whether they are managers, specialists or individual contri-

* The Boston Consulting Group / World Federation of Personnel Management Associations (BCG/WFPMA). Creating People Advantage 2011: Time to act: HR certainties in uncertain times, available at : https://www.bcgperspectives.com/content/articles/people_management_hu-man_ resources_creating_people_advantage_2011/. 
Toм H., c. $42-57$

\begin{tabular}{|l|l|}
\hline Future importance: high, low & Важливість у майбутньому: висока, низька \\
\hline Training and people development & Навчання і розвиток співробітників \\
\hline Talent management and leadership & Управління талантами і лідерство \\
\hline Recruiting: branding, hiring and onboarding & Рекрутинг: брендинг, наймання і адаптація \\
\hline Engagement, behavior, and culture management & Залученість, поведінка і культура управління \\
\hline $\begin{array}{l}\text { HR analytics: strategic workforce planning and } \\
\text { HR/workforce reporting }\end{array}$ & $\begin{array}{l}\text { НR-аналітика: стратегічне кадрове планування і } \\
\text { НR/кадрова звітність }\end{array}$ \\
\hline Performance management and rewards & Управління ефективністю і винагороди \\
\hline Labor costs, flexibility, and restructuring & Затрати на оплату праці, гнучкість і реструктуризація \\
\hline HR communications and social media & НR комунікації та соціальні медіа \\
\hline HR target operating model & Цільова операційна модель НR \\
\hline Diversity and generation management & Управління різноманітністю і поколіннями \\
\hline Current capability: high, low & Поточні можливості \\
\hline Sample size: 2,304 & Розмір вибірки: 2зо4 \\
\hline Medium need to act & Середня потреба діяти \\
\hline Strong need to act & Сильна потреба діяти \\
\hline Low need to act & Низька потреба діяти \\
\hline Effort invested: low, high & Докладені зусилля: низькі, високі \\
\hline
\end{tabular}

в) Управління талантами і лідерство, як і раніше, є найважливішими, за ними йдуть аналітика і залучення - більша частина зусиль спрямована на навчання Рис. Динаміка складових управління персоналом

Наступне дослідження, яке було проведене у 35 європейських країнах і охопило 2039 фахівців у сфері менеджменту персоналу, дозволило зробити аналогічні висновки * [2]. Як ілюструє цей огляд, у галузі підтримки талановитих випускників вищих навчальних закладів за посередництвом “практикантських програм" у німецькомовній Європі вже напрацьовано солідні креативні знання, тому нашою метою є спонукання до дії відповідальних осіб у галузі людських ресурсів по всьому світу, а також постачання для них нових ідей. Для цього наведемо ряд попередніх зауважень про поняття “талановита молодь” та управління нею.

Найчастіше під терміном “талант” розуміють особливе обдарування в якійсь галузі людської діяльності або особу, яка має такі риси. У вужчому, професійному, значенні в середовищі менеджменту персоналу для талановитих осіб є спільним те, що вони зазвичай володіють вищою фаховою освітою. Вона необов'язково прив'язується до академічної сфери, якщо йдеться про особливо обдарованих ремісників - наприклад, висококваліфікований кухар або надзвичайно обдарований ювелір. До того ж талановиті люди демонструють високу професійну мотивацію та радість від наявності завдань, які вимагають неординарних якостей. У них є потреба у професійному вдосконаленні, до чого вони й самі постійно прагнуть. Особливо талановитими вважаються ті особи, яким додатково притаманні соціально виражені компетенції (готовність до комунікації та кооперації). Талановита людина володіє тими ключовими кваліфікаціями, які є особливо необхідними та важливими для подальшого позитивного розвитку та сукупного успіху компанії.

Автори зазначеного дослідження БКГ трактують завдання управління талановитою молоддю так: “Ідеться про залучення, розвиток та задіяння всіх працівників з високим потенціалом на всіх організаційних щаблях - незважаючи на те, чи це менедже-

* The Boston Consulting Group / World Federation of Personnel Management Associations (BCG/WFPMA). Creating People Advantage, 2011: Time to act: HR certainties in uncertain times [Електронний ресурс]. - Режим доступу : https://www.bcgperspectives.com/content/articles/ people_management_hu-man_resources_creating_people_advantage_2011/. 
butors - across all levels of the organization”. Experts in the field generally like to speak of a "high potential" in people with talent. Often talented employees work in positions where they cannot make use of their maximum levels of performance. In the literature, the concept of "high potential" applies to those who both show maximum performance in their current position while having a lot of remaining potential for development. In any case, talented young employees are supposed to have or to develop towards this status of high potential.

In the understanding of the present author and his research collaborators, talent management takes the shape of a cross-domain process within the company's overall HR management scheme. Talent management is a task shared between line and HR managers. The two need to cooperate when it comes to attracting talented people, introducing them to the organization, assessing their performance and potential, developing their skills and retaining their capability and willingness to perform within the company. On this view, talent management (attraction, introduction, assessment, development and retention of talent) is affected by five overarching functions of HR management:

1. Strategic HR management. Strategic HR management is concerned with adjusting the HR strategy (how much staff with what skills will we require in the future?) to the overall company strategy (on which markets do we want to compete, using what kind of competitive strategy?). This will clarify not only what kind of talent will be needed where and when, but also what objectives the organization can achieve through talent in the first place.

2. Organization of HR management. Who (line managers, own and external HR specialists) is assigned which tasks in talent management, with what capacities (decisionmaking and other authority) and responsibilities? How to organize the sub-processes of talent management?

3. HR planning. HR planning must be coordinated with corporate planning in other domains (e.g. sales, production and financial planning). This part of operational planning specifies personnel requirements in both quantitative and qualitative terms and clarifies what kind of talent management the company can afford.

4. HR marketing. The task here is to increase the employer's attractiveness on the relevant labor markets. For this purpose, the company must know the needs of target groups (in this case, talented jobseekers) and must offer appropriate incentives.

5. HR controlling. This comprises continual monitoring of the key figures that are relevant in the tailoring of all activities to the objectives pursued. Certainly relevant to talent management are, for instance, figures on the duration of stay in specific positions, results of performance assessment, job satisfaction, and activities and advances in further education.

By means of trainee programmes (henceforth: $\operatorname{TrPr}$ ), employers aim to establish a corporate pool of qualified and highly motivated young professionals. To the extent that they possess the characteristic features of talented workers mentioned above, former trainees may go on to enjoy continued special fostering and be promoted to positions with more complex task profiles. On the classical view in the German-speaking world, however, no one is "a talent forever" just because they have participated in a corresponding programme at some point. New decisions are made after every stage of testing the candidate's worth as to whether they are still part - and still want to be part - of the talent pool.

The present author has continuously observed and, together with his collaborators, done research on $\operatorname{TrPr}$ since the 1970s. One of his own early definitions of $\operatorname{Tr} P r$ specified 
ри, спеціалісти або окремі працівники”. Фахові автори постійно говорять про “високий потенціал” особи з талантом, оскільки дуже часто талановиті працівники ще не досягли найвищого рівня результативності на робочому місці, яке вони на даний час займають. Роль талановитих працівників є дуже високою, але їх таланти використовуються недостатньо. Таким є вердикт досліджень з управління талановитою молоддю.

Можливістю, яку дуже часто застосовують для управління талановитою молоддю, є так звані “практикантські програми”. Проте для їх ефективної реалізації необхідно усунути окремі недоліки, наприклад, той факт, що в кандидатському профілі або річних завданнях безпосереднього керівника практиканта не оцінюється (або оцінюється недостатньо) супровід останнього. Отже, маємо не стільки брак часу, скільки відсутність сприйняття важливості цієї роботи. Таким чином, необхідними є підтримка з боку вищих керівників підприємства та інтеграція "практикантських програм” у концепцію розвитку персоналу. За умови наявності обох передумов, а саме високої результативності на займаній посаді та високого потенціалу розвитку, у фаховій літературі прийнято говорити про “високий потенціал" (High Potentials). Taланти слід розвивати у напрямі досягнення ними статусу “високопотенціальних".

Під управлінням талановитою молоддю автор розуміє процес, який має якнайбільше охоплювати управління персоналом і стосуватися саме нього. Інакше кажучи, управління талановитими кадрами - це спільне завдання, з одного боку, керівної ланки, а з іншого - спеціалістів з управління персоналом. Обидві сторони повинні співпрацювати з метою залучення талановитих кадрів, їх ознайомлення із структурою підприємства, оцінки їх результатів і потенціалів, подальшого розвитку їх компетенцій, а також досягнення високої працездатності та готовності до вищих результатів на користь роботодавця. 3 огляду на це, залучення, ознайомлення, оцінка, розвиток, утримання талантів та управління ними мають скеровуватися такими п'ятьма провідними функціями управління персоналом.

1. Стратегічне управління персоналом. Ставить на меті узгодження стратегії з розвитку персоналу (скільки персоналу і з якими якостями треба буде в майбутньому?) із стратегією розвитку підприємства (на яких ринках працює підприємство і яка стратегія конкурентоспроможності при цьому використовується?). Це дозволить не тільки з'ясувати який саме талант, де і коли знадобиться, але й те, які цілі організація може досягти за допомогою таланту у першу чергу.

2. Організація управління персоналом. Хто саме (рядова ланка, спеціалісти відділу кадрів) управляє талановитими кадрами, які завдання перед ними ставляться, які повноваження при цьому їм надаються та яку відповідальність вони несуть? Як необхідно організовувати складові процесу управління талановитою молоддю?

3. Планування персоналу. На основі оперативного планування (планування збуту, виробництва та фінансування) уточнюються і з'ясовуються кількісні та якісні характеристики потреби в персоналі, а також обсяг фінансування цих програм.

4. Маркетинг персоналу. Для збільшення привабливості роботодавця на відповідних ринках праці він повинен ознайомитися з потребами цільової групи (талановитою молоддю) і запропонувати відповідні стимули.

5. Контроль персоналу. Проводиться постійний аналіз ключових даних з метою відповідного коригування всіх заходів, необхідних для досягнення поставлених цілей. Для управління талановитими кадрами важливо проаналізувати ключові дані щодо часу перебування на окремих посадах, результати оцінки ефективності, ступінь задоволення від роботи, а також виявлення активності та здобуття успіхів у підвищенні кваліфікації.

За допомогою ПрП роботодавці хочуть створити на своїх підприємствах пул кваліфікованих і мотивованих молодих кадрів. Щойно вони почнуть відповідати названим характеристикам талановитого персоналу, колишні практиканти можуть отримати подальшу підтримку і піднятися кар'єрними сходинками до посад із складнішим профілем завдань. Згідно з прийнятою в німецькомовному просторі думкою, не існує жодних “довгострокових талантів” лише на підставі того, що вони одноразово взяли 
that they were "supposed to allow a select circle of university graduates to receive basic training preparing for future management positions, to become clearer about their capabilities and interests, to establish personal relations and to become familiar with the corporate structure and culture of an organization" [3, p. 218].

Today, talk of a "select circle" is still appropriate in connection with attractive employers, where usually numerous candidates apply for any available programme position. Often, complex procedures are used in selecting the most suitable individuals. Other parts of the definition, however, require modification from a contemporary viewpoint. "Future management positions", for one thing, must be made more precise: while former trainee programme participants continue to be candidates for line management careers and in some companies have indeed reached top management positions, many of today's employers also offer opportunities for technical specialists or project managers as an alternative to classical management careers. Furthermore, research suggests that the learning objectives sketched in the definition should be spelled out and completed as follows:

1. Education. The educational objective still is fundamental. After completion of the programme, trainees should be prepared for a job at management assistant level that is adequate to their formal education (e.g. junior controller, product manager, HR manager).

2. Information. Also an informational objective remains firmly in place. Trainees are supposed to get to know the company and to become more reassured about their own personal performance capacities and their preferences regarding the subsequent stages of their professional lives. Employers for their part hope to learn as much as possible about the abilities and interests of each individual trainee.

3. Integration. The objective of integration amounts to the trainee's deeper understanding and internalizing of the corporate culture - or, more precisely, of the system of core values to which each of the visited departments subscribes.

4. Image. The image objective captures the employer's aim to attract as many excellently qualified applicants as possible. Employer attractiveness is to be raised on the talent labor market (i.e. particularly among advanced students on relevant university courses).

5. Sustainability. $\operatorname{TrPr}$ are a costly matter; from an accountancy viewpoint, they are an investment. Accordingly, an adequate return in the form of work in the employer's service is expected after the TrPr. Thus, pursuing a sustainability objective, the employer strives to make trainees stay in the company for a certain amount of time (e.g. three years) after completion of the programme.

At this point, the obvious question arises as to how all these objectives on the part of both trainees and employers can be achieved to the greatest possible degree. Research by the author and his collaborators has produced a considerable base of knowledge in this regard - relating, for instance, to the duration of $\operatorname{TrPr}$, their customization versus standardization, the importance of stays abroad, different programme types, or recurrent problems in TrPr implementation. Some of the most important and practical insights gained in the course of this work are discussed in the next section. In doing so, special prominence is given to the most recent large-scale research project on $\operatorname{TrPr}$ supervised by the author, completed in 2012 at the University of Bern and presented in detail in the monography [4]. The mentioned study rests on an empirical basis of 130 companies in German-speaking Europe. TrPr are more widespread in the services (banking, trade, insurance) than in the industrial sector (63\% versus $37 \%$ ). They have an average length of 
участь у програмі підтримки. Після проходження окремих фаз перевірки заново вирішують, чи працівник ще належить (або бажає належати) до групи талановитих кадрів.

Ще з середини 1970-х років автор постійно спостерігає та досліджує ПрП для випускників вищих навчальних закладів. Попереднє визначення цих програм звучало так: “програми ПрП мають дозволяти певному колу випускників ВНЗ здобувати базову освіту для підготовки до майбутніх керівних посад, щоб краще зрозуміти свої можливості та інтереси, встановити особисті відносини та ознайомитися з корпоративною структурою і культурою організації” [3, p. 218].

Як і раніше, “обране коло” стосується насамперед роботодавців з високим рівнем популярності, оскільки за кожне практикантське місце змагаються численні кандидати; серед них, під час скрупульозної процедури, обирається практикант. Якщо взяти до уваги інші робочі місця, то, з сучасної точки зору, дефініцію необхідно відкоригувати. Опцію “подальше зайняття керівних посад” необхідно доповнити таким: незважаючи на те, що багато колишніх практикантів і досі посідають керівні посади, а на деяких підприємствах досягли позицій провідних управлінців, проте нині багато роботодавців пропонують як альтернативу кар'єрне зростання на посадах у вузькопрофесійних і проектних сферах. Відповідно до актуальних досліджень, дефініція визначених цілей навчання для практикантів надалі має бути доповнена таким переліком.

1. Навчання. Йдеться про досягнення цілей освіти. Після завершення програми практиканту має надаватися можливість для самостійної діяльності, яка б відповідала суті навчання і реалізовувалася на посаді практичного виконавця (наприклад, молодшого контролера, продакт-менеджера (менеджер з певного виду продукціі), фахівця 3 персоналу).

2. Інформація. Йдеться про досягнення інформативної мети. Практикант повинен ознайомитися з підприємством, його результативністю, а також власними преференціями для наступних професійних етапів. Із свого боку, роботодавець хоче більше дізнатися про здібності та схильності практиканта.

3. Соціалізація. 3 метою досягнення соціалізації практикант має краще пізнати та перейняти культуру підприємства, осягнути практичну цінність відвідуваних підрозділів.

4. Імідж. За допомогою іміджевої мети роботодавцю слід залучити якомога більше оптимально кваліфікованих претендентів. Вони повинні підвищувати свою привабливість на ринку молодих талановитих кадрів, насамперед у середовищі успішних студентів відповідних спеціальностей.

5. Ефективність. ПрП вимагає значних витрат, являючи собою інвестицію всередині підприємства. Відповідно, варто очікувати певного повернення коштів у формі виконаної роботи після завершення ПрП. Отже, роботодавці прагнуть досягти того, щоб практиканти після завершення навчання відпрацювали в нього певний час (мінімум 3 роки).

Виникає запитання: “Як найкраще досягти всіх зазначених цілей, причому як практикантом, так і роботодавцем?”. Щодо цього в німецькомовному просторі зібрано досить багато знань. В університетських дослідженнях виокремлюють довгострокові тенденції, а саме щодо тривалості ПрП, індивідуалізації або, навпаки, стандартизації, значення перебування за кордоном, різноманітності типів програм, частих проблем при їх реалізації тощо. Деякі з найважливіших практичних висновків 3 даних праць потім коротко висвітлюються. При цьому особлива увага приділяється великомасштабному дослідницькому проекту, який побудовано на численних попередніх дослідженнях і перебуває під науковим керівництвом автора цієї статті [4]. Дослідження спирається на емпіричний досвід 130 підприємств у німецькомовному просторі. Практикантські освітні програми більш поширені в галузях з надання по- 
about 18 months, during which the trainees usually proceed through four or five training positions. The crucial hypotheses confirmed by the study are the following:

Hypothesis 1. The amount of time spent by trainees' direct superiors on the $\operatorname{Tr} \operatorname{Pr}$ as a whole has a positive impact both on the objective of integration and the technical educational objective. A huge - perhaps the greatest - obstacle to a successful $\operatorname{Tr} \operatorname{Pr}$ is excessive demands on the time of the trainees' superiors. In the course of the programme, trainees shift between various departments (e.g. sales, accounting, HR). An implicit presumption here is that the various departments' superiors have enough time to impart valuable practical and theoretical knowledge to the trainees. However, numerous empirical studies have revealed lack of time on the part of superiors to be a serious problem that jeopardizes several of the objectives of $\operatorname{TrPr}$ listed above. This is evident with regard to the educational objective, but also familiarization with values (objective of integration) may be hampered, along with other aims. In a series of workshops with $\operatorname{Tr} P r$ responsibles organized by the present author, one important reason for time shortage was identified: in both the job profiles (job descriptions) and the annual objectives of superiors, the objectives of $\operatorname{TrPr}$ tend to rank only very low or even do not figure at all. This simple circumstance seriously endangers the success of $\operatorname{TrPr}$ and thus an essential component of talent management as a whole.

Hypothesis 2. A visible effort on the part of the company's top management in favor of $\operatorname{TrPr}$ adds to a positive internal image of $\operatorname{TrPr}$.

A positive internal image means enhanced acceptance of TrPr within the organization and, in particular, stronger support of $\mathrm{TrPr}$ on the part of direct superiors, which will alleviate the problem discussed under (1) above. It is the top management alone that has the power to ensure the long-term existence of $\operatorname{TrPr}$.

Hypothesis 3. A mentoring programme within $\operatorname{TrPr}$ may contribute to a positive external image of TrPr. Learning from a mentor need not be restricted to technical knowhow, but may include informal relations and power structures; it can facilitate access to networks and thus accelerate the process of integration of the trainee. Through such personal interaction, trainees may also become better at assessing their own performance and potential. Thus a whole range of objectives would seem to be pursuable through mentoring. Statistical proof, however, is only forthcoming for a positive effect on the external image objective.

Hypothesis 4. Project work in the course of TrPr has a positive impact on the objective of integration and the technical and methodical educational objectives of TrPr. Project work can take various forms. Projects may be small and restricted to individual training stages and positions. Less common are larger projects involving informational stays in various organizational departments. Projects are complexes of tasks that come with deadlines. They are oriented towards precise goals (adhering to time and cost limits, attaining quality standards, etc.), thus making it possible for $\operatorname{TrPr}$ to have participants take considerable responsibility. The methodical educational objective comprises, among other things, training in group work and presentation techniques or methods of project work (e.g. time and cost planning).

Hypothesis 5. Stays abroad enable trainees to acquire intercultural competence as part of the educational objective of $\operatorname{Tr} P r$. Intercultural competence is a special variety of social skill. It is the ability to interact with people from foreign cultures in adequate and effective ways. A distinction can be made here between a cognitive level (e.g. linguistic, historical, geographical knowledge), an emotional level (e.g. empathy) and a practical level (communication skills, etc.). As an element in the training of talented young profes- 
слуг - 63\% (у середовищі банків, торговельних підприємств, страхових товариств) проти $37 \%$ у середовищі промислових підприємств. У середньому навчання триває приблизно 18 місяців. Зазвичай практиканти проходять 4-5 освітніх рівнів. Найважливіші тези, підтверджені дослідженням, такі.

Гіпотеза 1. Участь прямого керівника практиканта у ПрП позитивно впливає як на ціль соціалізації ПрП, так і на фахову мету навчання. Велика (можливо, навіть найбільша) проблема для успішної ПрП - це часове перевантаження відповідного керівника практиканта. Практиканти під час навчання постійно змінюють фахові підрозділи. В ідеалі відповідні керівники фахових підрозділів повинні мати час на передання практикантові “ноу-хау” і демонстрування причинно-наслідкових зв’язків. У численних емпіричних дослідженнях вказується на брак часу у безпосереднього керівника як на серйозну проблему, що перешкоджає реалізації відразу декількох із зазначених цілей ПрП. Це особливо актуально для досягнення поставлених цілей навчання, проте і передання цінностей (мета соціалізації) залишається недосяжним. Під час проведення цілого ряду колоквіумів для осіб, відповідальних за проведення ПрП, викристалізувалася причина відсутності часу - в заявках на кандидатів і річних завданнях цілі навчання практиканта або не знаходять місця, або отримують лише незначну оцінку. Ця проста обставина загрожує успіху ПрП, і таким чином є важливим компонентом управління талановитою молоддю у цілому.

Гіпотеза 2. Помітна участь керівництва підприємства у ПрП позитивно впливає на досягнення ії іміджевої цілі. Позитивний внутрішній імідж покращує сприйняття ПрП усередині підприємства. Це сприяє ії підтримці з боку фахових керівників підрозділів і допомагає пом'якшити проблеми, висвітлені в гіпотезі 1. Керівництво підприємства - це та група людей, яка довгостроково гарантує саме існування ПрП.

Гіпотеза 3. Програма наставництва в рамках ПрП позитивно впливає на досягнення іiі зовнішньої іміджевої цілі. Навчання під керівництвом наставника не обмежується лише фаховим змістом, а скеровується на неформальні структури як у стосунках, так і у владних кабінетах, допомагає доступу до мереж і підтримує процес соціалізації практиканта. Можливо, саме через такі знайомства практикант зможе краще оцінити власні результати та пізнати свій потенціал. Таким чином, за посередництвом наставництва у принципі можна досягти реалізації декількох цілей ПрП, проте статистично доведений факт, що це має позитивний вплив лише на досягнення зовнішньої іміджевої цілі.

Гіпотеза 4. Робота над проектом у ПрП добре впливає на досягнення мети соціалізації, а також іiї фахових і методичних цілей. Проекти можуть бути невеликими та обмежуватися окремими етапами навчання і позиціями. Рідше це великий проект, пов'язаний з інформативним перебуванням у різних організаційних структурах. Проект - це комплекс завдань, обмежений у часі й скерований на досягнення чітких цілей (дотримання часових і фінансових критеріїв, якісних стандартів). Таким чином, навчання практиканта прив'язується до необхідності взяти на себе відповідальність. Методична ціль навчання охоплює вивчення технік групової роботи та презентацій, а також методів роботи над проектом.

Гіпотеза 5. Перебування за кордоном дозволяє набувати міжкультурної компетентності в рамках досягнення навчальних цілей ПрП. Міжкультурна компетентність - це особлива форма соціальних здібностей, а саме вміння обмеженим та ефективним способом інтегруватися з людьми іншого соціокультурного походження. Тут можна провести різницю між когнітивним (наприклад, лінгвістичним, історичним, географічним знанням) емоційним (емпатія) і практичним рівнем (навички спілкування та ін.). Такий важливий елемент у навчанні молодих талантів, як 
sionals that is continuously growing in importance, intercultural competence is best acquired through stays abroad - provided these are designed such that they actually allow, or indeed enforce, maximally intensive exchanges with the host culture.

Hypothesis 6. Integrating $\operatorname{TrPr}$ within corporate HR development is conducive to retaining participants in the company for a prolonged period of time after completion of the $\operatorname{TrPr}$, and thus to achieving a sustainability objective. Integration of $\operatorname{Tr} P r$ within comprehensive HR development schemes is often regarded as more or less a matter of course. However, true integration comprises a wide range of measures: early information on career and further education opportunities, continued mentoring after completion of the programme, regular assessment applying the same system that is used in the company's leadership development programme, integration of trainees in real teams and corporate project groups, personal commitment on the part of the company's top management for the $\operatorname{Tr} P r$ and its continued existence.

Over the past decades, a massive amount of know-how with regard to the intricacies of $\operatorname{Tr} P r$ as a talent management tool has been gathered in the German-speaking world. In other world regions, however, the huge potential of $\operatorname{Tr} P r$ as a corporate talent management tool remains to be exploited. Last but not least, the pedagogical role of $\operatorname{Tr} P r$ and their place in the broader educational and economic context are worth considering.

1. University graduates, particularly those in business administration and economics, tend to be capable, but not quite ready yet for entering the profession. Tailor-made forms of supplementary training at and by employers are required. In a sense, a $\operatorname{Tr} P r$ is a dual educational programme where theory-centred university courses are followed by more strictly regimented corporate training.

2. In German-speaking Europe, TrPr have by now been opened to graduates from socalled universities of applied sciences (UAS), i.e. institutions of higher education for people who have first completed an apprenticeship. On graduation from a UAS, usually with a bachelor degree, the great majority of students start their professional career. It is also possible, however, to go on studying for a master's degree, either at the UAS or at regular universities. This means that there is no need for a high percentage of an age-group to strive directly for tertiary education through one or another kind of purely theoretical university admission qualification (as is the case with most countries outside Germanspeaking Europe). As a rule, employability is considerably improved where such alternative educational paths exist. There is reason to assume a causal link here with the relatively low youth unemployment numbers in the German-speaking world.

3. Currently, developments are underway towards "dual study programmes": university students are formally employed by companies while studying for a bachelor or master's degree, where the academic courses include project and transfer work to additionally increase practical relevance. Steinbeis University in Germany is one example institution that has been collecting a lot of experience with this kind of programme for which it cooperates with renowned employers such as Daimler or Bosch.

4. The German-speaking countries are very much export-oriented and home to many international companies. Accordingly, stays abroad as an integral part of TrPr have grown in importance in recent decades. Where participants in trainee programmes do part of their training in foreign subsidiaries, this not only improves their intercultural competence; it may also contribute to corporate know-how export, thus enabling companies to benefit far beyond the immediate purposes of an established tool for fostering and managing talent. 
міжкультурна компетентність, найкраще можна освоїти протягом перебування за кордоном, якщо дотримано передумову - це перебування побудоване так, що уможливлює (або навіть змушує) до якомога інтенсивнішого обміну з культурою країни перебування.

Гіпотеза 6. Інтеграція ПрП у систему розвитку персоналу на підприємстві допомагає якомога довше утримувати практиканта на підприємстві після їі завершення, що, у свою чергу, дозволяє досягти такої мети, як ефективність. Залучення ПрП до всеохоплюючої системи розвитку персоналу дуже часто сприймається як здійсненний факт. Проте інтеграція пов'язана з великою кількістю заходів: вчасне демонстрування кар'єрних можливостей і шансів, отриманих від підвищення кваліфікації, підтримка наставницьких відносин після завершення ПрП, регулярне оцінювання практиканта за допомогою системи оцінювання для розвитку керівних кадрів, інтеграція практиканта в реальні команди та проектні групи на підприємстві, особиста участь керівництва підприємства в діяльності ПрП та ііі безперервний супровід.

У німецькомовному просторі за останні десятиліття напрацьовано багато знань про реалізацію ПрП як основний інструмент управління талановитою молоддю. У всьому світі існує значний потенціал для розширення можливостей ПрП у рамках управління талантами на підприємстві. Також не можна випускати з уваги і педагогічну роль “практикантських програм”, їх локалізацію в подальшому навчальнополітичному та економічному контексті.

1. Випускники вищих навчальних закладів, особливо економічних спеціальностей, після завершення навчання в цілому здатні, але ще не готові до професійної діяльності. Необхідно провести додаткове спеціальне навчання, скероване на потреби підприємства. У контексті ПрП ідеться про послідовну дуалістичну концепцію, згідно з якою після здобуття заснованої на теорії вищої освіти має відбуватися структуроване навчання на підприємстві.

2. У німецькомовному просторі ПрП є відкритими і для випускників вищих професійно-технічних навчальних закладів. До вищих професійно-технічних навчальних закладів (вищих навчальних закладів прикладних наук) вступають особи, які спочатку здобувають професійну освіту. Важливим є принцип доступності та прозорості. Тому більшість молоді після отримання атестата про середню освіту не повинна відразу вступати до університетів (як це прийнято в багатьох країнах за межами німецькомовного простору), оскільки існують альтернативи, завдяки яким посилюється пристосованість до потреб ринку праці. Можна припустити, що існує причинно-наслідковий зв’язок з низьким рівнем безробіття в німецькомовному просторі.

3. Тим часом подальший розвиток іде в напрямі дуалістичної вищої освіти: під час свого основного навчання студенти формально зайняті на підприємстві і паралельно завершують навчання за бакалаврською або магістерською програмою. Це дозволяє набути практичного досвіду за посередництвом у проектних і трансферних роботах. Наприклад, вищому навчальному закладу “Штайнбайз” (Штутгарт - Берлін) за допомогою цієї концепції вдалося набути значного авторитету - він співпрацює 3 такими відомими роботодавцями, як Daimleri Bosch.

4. Німецькомовні країни є експортоорієнтованими і виступають базою для багатьох міжнародних компаній. Тому для ПрП перебування за кордоном набуває дедалі більшого значення. Якщо практиканти проходитимуть частину навчання на дочірніх підприємствах за кордоном, то вони покращать не тільки свою міжкультурну компетентність, але й зроблять внесок в експорт “ноу-хау” за посередництвом перевіреної концепції підтримки молодих талантів. 


\section{References}

1. Thom N. Talent management through "trainee programmes". Conceptual preliminaries and research-based advice on the design of corporate educational programmes for University graduates. Organization and management, 2015, No. 1A (165), pp. 37-47.

2. Strack R. Certainties in uncertaintimes. Personalwirtschaft, Sonderheft, 2011, Iss. 1, pp. 14-17.

3. Thom, N. Personalentwicklung als Instrument der Unternehmungsführung. Stuttgart, 1987, p. 218.

4. Nesemann, K. Talent management durch Trainee-Programme. Wiesbaden, 2012.

The article was received by the Editorial staff on February 7, 2019. 


\section{Список використаної літератури}

1. Thom N. Talent management through "trainee programmes". Conceptual preliminaries and research-based advice on the design of corporate educational programmes for University graduates / Organization and management. - 2015. - No. 1A (165). - P. 37-47.

2. Strack R. Certainties in uncertain times / Personalwirtschaft, Sonderheft. - 2011. Iss. 1. - P. 14-17.

3. Thom $N$. Personalentwicklung als Instrument der Unternehmungsführung. Stuttgart, 1987. - P. 218.

4. Nesermann K. Talent management durch Trainee-Programme. - Wiesbaden, 2012.

Стаптя надійшла до редакції 7 лютого 2019 р. 